\title{
Deductibility of Provisions under the CCCTB Proposal and Its Effects on Companies: The Case of Poland
}

\author{
Anna Leszczyłowska*
}

\begin{abstract}
:
The aim of the paper is to empirically examine the scale and the distribution of the tax advantage which emerges when provisions for future liabilities are deductible from taxable earnings, as proposed in the CCCTB concept. The paper concentrates on Poland - a country for which the expected economic effects of this proposal are still controversial and ambiguous. The results are also relevant for other European countries in which provisions are currently treated in a different way for financial and for tax accounting purposes. The analysis is based on the information from financial statements of 250 companies from the period 2007-2012. The microsimulation method in a multi-period setting is implemented. The results show that in case provisions are deductible for tax purposes the tax due decreases by 5,6 $\%$ or and by $9,8 \%$ on average, depending on the liquidity situation of companies. The tax advantage is distributed differently among companies. The majority of taxpayers is expected to gain from the reform. Only for single companies there is an increase in tax, induced by the existing, restricted tax loss carry forward rules. The median change in CIT amounts to $-1 \%$ and $-2 \%$.
\end{abstract}

Key words: Corporate income tax; CCCTB; Provisions; Microsimulation; Poland. JEL classification: $\mathrm{H} 25, \mathrm{H} 32, \mathrm{~K} 34$.

\section{Introduction}

Creating provisions for future obligations is necessary to account for possible risks connected with different corporate activities and changing economic environment. Being recognized both in the balance sheet and, correspondingly, as costs in the profit and loss account, provisions are an important instrument of firm's accounting policy. EU member states implement diverse practices as far as the treatment of provisions for corporate income tax purposes is concerned. While some of them allow tax-effective deduction of provisions when they are created, the majority of countries recognize tax deductible expenses only in periods when actual payment is made. This is crucial in the context of the harmonization of business income taxation within the European Union. Since the Draft Council directive on a common consolidated corporate tax base $(\mathrm{CCCTB})^{1}$ allows to

Anna Leszczyłowska, PhD.; Research Assistant; Department of Corporate Finance, Faculty of Management, Poznań University of Economics and Business, al. Niepodległości 10, 61-875 Poznań, Poland, <anna.leszczylowska@ue.poznan.pl>.

1 Proposal for a Council Directive on a Common Consolidated Corporate Tax Base (CCCTB), European Commission, COM (2011) 121/4. 
Leszczyłowska, A.: Deductibility of Provisions under the CCCTB Proposal and Its Effects on Companies: The Case of Poland.

deduct provisions from taxable earnings, questions connected with their recognition and measurement gain in importance. The problem of provisions appears as one of the major differences between the harmonization project and the national tax accounting practices across the EU.

Recent works on the proposal of the Council's directive on the common consolidated corporate tax base revealed that there are far-reaching differences in the tax treatment of provisions across the EU member states. Only 9 countries ${ }^{2}$ allow tax-effective deduction of provisions while the remaining member states generally recognize tax deductible expenses only when actual payment is made (Spengel and Zöllkau (Ed.), 2012, p. 50). Since no type of provisions is accepted by the Polish tax law, Poland can be seen as an example of countries for which the regulations on the recognition and measurement of provisions as proposed by the draft CCCTB directive are expected to cause considerable changes to the existing national tax practices (Spengel et al., 2012, pp. 12-14). Against this background, it is interesting to investigate what the possible effects of tax-effective deduction of provisions from the perspective of companies are.

The aim of the paper is to empirically examine what the scale and the distribution of the tax advantage which emerges when provisions for future liabilities are deductible from taxable earnings, as proposed in the CCCTB concept is.

The paper contributes both to the ongoing discussion on the harmonization concept of the corporate income tax within the EU and to the current debate regarding book-tax differences. It uses a modern method of microsimulation which has not been widely used in corporate income tax research yet. Moreover, based on empirical data of Polish companies, the article gives insights into the consequences which may be similar also in other jurisdictions in which provisions for future liabilities are treated differently in financial and tax accounting.

The paper is structured as follows. The second section provides a brief insight into the current research on the consequences of the common European corporate tax base. The third section addresses different categories of provisions in the CCCTB directive and the national tax practice and discusses them in the context of the empirical research carried out in the paper. The fourth part of the paper presents the underlying empirical data and the microsimulation methodology implemented. In the fifth section the results of the microsimulation are presented. The last part of the paper concludes.

2 Austria, Belgium, France, Germany, Ireland, Luxemburg, Netherlands, Slovenia, Spain. 


\section{Literature review}

The initial idea of the CCCTB (common consolidated corporate tax base with consolidation and apportionment) has seemed to be hardly feasible for political reasons so far. For this reason, a less far-reaching concept of the CCTB (common rules concerning the determination of the tax base without consolidation and apportionment) is currently seen as a reasonable alternative. There was a lot of debate according to the possible linkage between the CCCTB and IFRS. Finally, the proposal of the directive has no formal connections to the accounting standards and it develops its own definition of taxable income (e.g. Spengel and Zöllkau (2012), Vašek and Gluzová (2014)). While there are several simulation studies on the consequences of the Council's proposal on the tax burden and tax revenues of the EU member states, they focus rather on the CCCTB-variant of the concept. They analyse possible revenue, some of them also macroeconomic, effects of different scenarios concerning the consolidation and apportionment of the tax base. For instance, McLure and Weiner (2000) assessed the consequences of different allocation factors. Fuest et al. (2007) as well as Devereux and Loretz (2008) analysed the effects of formula apportionment on the size of the tax base in Germany and in EU member states, respectively. Oestreicher and Koch (2011) investigated the key elements that factor into the tax-revenue consequences for different EU member states. Cline et al. (2011) studied revenue as well as macroeconomic effects of an EU-wide CCCTB. Nerudová and Solilová (2014) made a comparison of revenue consequences of the CCCTB among European countries. Nerudová and Solilová (2015) assessed the impact of formula apportionment on the tax base in the Czech Republic. A comprehensive impact assessment considering the effects on the size of the tax base, its distribution among the EU member states and the influence on different macroeconomic factors was provided by the European Commission (2011). These studies use various data sets and methodologies and are also based on different assumptions concerning the detailed shape of the concept and its optionality.

By contrast, there is a relatively smaller number of studies concentrating on the detailed rules governing various aspects of the determination of the tax base and the timing of profit recognition. Spengel and Zöllkau (2012) provided an in-depth legal analysis of the differences between the tax base determined under the rules in the proposed Council's directive and current national tax practices. Oestreicher et al. (2009) implemented a model firm approach to assess the consequences which an adoption of a CCTB would have on effective tax burdens of companies located in different EU member states. The analysed tax accounting rules comprised eight elements of the tax base: depreciation rules, valuation of inventories, determination of production costs, treatment of $R \& D$ costs, provisions for future pension payments, provisions for legal obligations, avoidance of double taxation of dividend income and loss relief. This research was further developed in Spengel 
Leszczyłowska, A.: Deductibility of Provisions under the CCCTB Proposal and Its Effects on Companies: The Case of Poland.

et al. (2012), after the proposal of the directive was released. The authors postulated that the harmonized rules on the corporate income tax should be introduced in two steps. The first one (CCTB) would only affect the calculation of the tax base. Their investigation was also aimed at quantifying the changes in effective tax burdens induced by the introduction of the CCTB in each of the EU member states, Switzerland and the U.S. Leszczyłowska (2013) analysed the effects of selected CCTB regulations on the tax burden of a group of Polish public companies with static microsimulation. The latest study on the effects of the CCTB in Germany was carried out by Oestreicher et al. (2014). The effects on company's tax burden were analysed using a microsimulation approach. This research concentrated on the detailed rules governing depreciation, pension provisions, other provisions and loss offset.

\section{Provisions in the CCCTB proposal and implications for the research design}

According to articles 25 and 26 of the Council's directive provisions are deductible provided that there is a legal obligation, or a probable future legal obligation, arising from activities or transactions carried out in that or previous tax years. It means that creating provisions voluntary i.e. in case of constructive obligations (if there is an established pattern of past practice), as e.g. for deferred repair and maintenance, is not allowed (Spengel and Zöllkau (Ed.), 2012, p. 51). Moreover, provisions have to result in deductible expenses. Thus, it has to be interpreted that pension provisions, provisions for contingent losses and liabilities as well as guarantee provisions are within the scope of the directive.

Another important point is the valuation of provisions. They should be reliably estimated based on all relevant factors, including past experience of the company, group or industry. The directive provides that in case of pension provisions actuarial techniques shall be used. In general, provisions with the term of over 12 months should be discounted. If there is no agreed discount rate, the provision shall be discounted at the yearly average of the Euro Interbank Offered Rate of the European Central Bank (Euribor) for obligations with a maturity of 12 months.

Admittedly, the majority of expenses which the provisions are created for are deductible for income tax purposes in Poland but only later, in periods in which these expenses become effective. Notwithstanding the tax accounting regulations, different categories of provisions are recognized in the financial accounting system. Creating provisions influences the amount of expenses and firm's profitability. The Polish accounting act mentions several categories of provisions. The main two groups are: provisions for employee benefits and other provisions. The former embraces i.a.: pension provisions established for future retirement 
severance pays as well as jubilee benefits. The latter contains: provisions for contingent losses, guarantee provisions, provisions for deferred repair and maintenance as well as for company's restructuring. Both types of provisions can be recognized either as long-term (with the maturity of over one year) or as short term items. It is evident that the deductibility of provisions may play an important role for tax purposes since in the sample of the analysed 218 firms over $83 \%$ of companies report them in their balance sheets in at least one year within the analysed period ${ }^{3}$. Pension provisions as well as other provisions are important in the context of the CCTB since they are created by $74 \%$ and $72 \%$ of companies respectively. As far as the structure of provisions is concerned, pension provisions have the greatest share in total provisions which amounts to 62\% (long-term positions predominate). The share of 'other provisions' in the total amount is $38 \%$ (in this group, short term provisions are created much more often than the longterm ones).

\section{Methodology and Data}

\subsection{Deriving the tax base from the financial statements}

Since tax returns of companies subject to the Polish corporate income tax are not accessible it becomes necessary to adjust the information from the financial statements in order to determine the amount of the tax due. An approach often used in literature aims at approximating certain items influencing the taxable base. In this way, various positions of expenses and allowances are subtracted from taxable earnings which, finally, enables to calculate the tax base. A potential shortcoming of this approach is connected with the fact that in jurisdictions characterized by little book-tax conformity (e.g. the case of Poland) the notions of earnings and expenses for financial accounting may differ strongly from these used for tax purposes. In consequence, the amount of business profit established in line with commercial accounting rules may not move close to the taxable income. Till this end, the amount of corporate income tax as stated in profit and loss account can be used to calculate the taxable base. However, it has to be proved whether this position consists of the annual tax due only or it embraces also deferred tax.

Polish accounting act obliges firms which fulfil at least two out of three conditions concerning sales, assets and employment to report deferred tax assets and liabilities. In the group of the analysed companies the deferred tax plays an important role. For this reason, relying exclusively on the information on the income tax as given in the profit and loss account, without proving whether a deferred tax is reported or not, would lead to distorted results which would not

3 The underlying empirical data is presented in detail in section 4.3. 
Leszczyłowska, A.: Deductibility of Provisions under the CCCTB Proposal and Its Effects on Companies: The Case of Poland.

reflect the real annual tax burden. For this reason, information on deferred tax assets and liabilities has to be utilized in order to derive the tax due, according to the methodology proposed by Leszczyłowska (2014). The tax due is derived by correcting the position "income tax" from profit and loss accounts by the annual change in deferred tax assets and deferred tax liabilities. It is calculated according to equation 1 :

$$
\operatorname{ITD}_{n}=\operatorname{IT}_{n}-\left(\mathrm{L}_{n}-\mathrm{Ln}_{\mathrm{n}-1}\right)+\left(\mathrm{A}_{\mathrm{n}}-\mathrm{An}_{\mathrm{n}-1}\right),
$$

Where ITD is income tax due, year $n$; $\mathrm{IT}_{\mathrm{n}}$ means income tax in profit and loss accounts, year $n$; Ln is used for deferred tax liabilities, end of year $n$; $\mathrm{Ln}-1$ is used for deferred tax liabilities, end of year $n-1$; An expresses deferred tax assets, end of year $n$ and $\mathrm{A}_{n-1}$ expresses deferred tax assets, end of year $n-1$.

\subsection{Deducting provisions from taxable earnings and measuring the effects}

In a next step, it should be checked to what extent the recognition of the two main categories of provisions influences the company's individual tax burden. A starting point of the simulation analysis refers to the initial tax base. The periodical tax base has to be corrected by new provisions made and old provisions released every year. In order to do that, it is necessary to trace back the development of these financial items over time. The procedure is based on that implemented by Reister et al. (2008) and Reister (2009) who applied the methodology of investment vintages to explain the composition of provisions for warranty obligations and contingent liabilities. However, the model implemented in this paper is first and foremost based on the information on the time structure of provisions as given in firm's balance sheet. Due to the similarity between the rules on provisions as established by the directive and the current accounting rules the information necessary for further analysis can be derived from firm's financial statements. In order to utilize the data, three questions have to be clarified.

First, it is important to find out whether all provisions revealed in the financial accounting system are recognized also by the directive. At this stage of the development of the CCTB-concept only provisions for deferred repair and maintenance should be excluded from the preferential treatment for tax purposes, in other words they are not to be deducted ${ }^{4}$.

Second, it has to be decided whether all provisions created for financial accounting purposes reflect deductible expenses for the income tax purposes. Although there are some categories of expenditures which are not accepted in the income tax rules

\footnotetext{
4 It is assumed that they constitute on average $5 \%$ of the position 'other provisions'.
} 
(as for instance penalties), the vast majority of expenses is allowed to be deducted $^{5}$.

A third crucial point is the valuation of provisions. Since some of them are recognized in the balance sheet at discounted values it has to be decided whether, and if so, it should be accounted in the simulation. It is assumed, based on legal requirements, that 'other provisions' (in which guarantee provisions are expected to predominate) are created for 2 years. This implies that the discounting of provisions can be neglected. This assumption is justified since the current accounting regulations do not provide any consistent discounting procedure. In consequence, it cannot be decided whether provisions in individual financial statements are reported at discounted values or not. Moreover, even if discounting was undertaken by some firms it did not influence the values much due to the short period ${ }^{6}$. Similar considerations are connected with valuation of pension provisions. Again, according to Polish accounting regulations there is no consistent system of valuing them. On the one hand employing actuaries is advised, on the other hand firms are also allowed to make the calculations on their own. Because of this, it would be extremely difficult and also arbitrary to trace back the development of pension provisions over time in the reference scenario and then to replace the discount rate which was preliminary used with the EURIBOR rate 7 . However, since it is more probable that this category of provisions was subject to discounting, the annual increases in values, which result from discounting over a shorter period of time, are included in the analysis ${ }^{8}$.

In a further step, after the annual changes in provisions (increases and decreases) are identified, the initial tax bases of companies are modified in order to calculate the tax base in the CCTB scenario. Possible tax losses are carried forward in line with the current corporate tax regulations. The loss carry forward is restricted to five years and a maximum of $50 \%$ of the initial loss can be deducted each year. Then, the firm-specific taxes due are derived and changes in the individual annual tax liabilities are analysed.

The microsimulation implemented in this paper uses financial information for five consecutive years. The multi-period perspective applied is appropriate to cover the timing effects of tax regulations on provisions. Looking at a single period only

5 This share is assumed to reach the level of $80 \%$.

6 When omitting discounting of 'other provisions', the potential inaccuracies may work in two opposite directions. For firms which did not undertake discounting the decrease in the tax burden is overestimated. In turn, for firms which report provisions at values discounted with a percentage rate higher than yearly EURIBOR the decrease in the tax burden is underestimated.

7 As a consequence, the decrease of the tax burden may be underestimated.

8 The discount rate is assumed to equal $4 \%$ since this value is an approximation of the average profitability of Polish treasury bonds. 
could be misleading since the opposite changes in the tax base to which it comes within a period of several years would not be taken into account. This approach is based on Reister (2009) and Finke et al. (2012). The simulation is static (it does not capture behavioural responses to changes in tax).

The tax due for every firm-year observation, for the reference scenario and the CCTB, is calculated using the nominal tax rate 9 . In the last step, the changes in long-term income taxes due for every analysed company are derived. In order to gain a more detailed insight into these changes its distribution among the taxpayers is subject to analysis using percentiles and histograms. The analysed companies are divided into two groups according to their overall liquidity situation (cash flow) ${ }^{10}$. The future values of the annual taxes due as well as cash flows are calculated for the end of the last observed year ${ }^{11}$.

\subsection{Data}

The calculations are based on the data on corporations carrying out the economic activity in Poland. The information is derived from the InfoCredit database, which provides detailed financial information on the entire population of companies in Poland. Initially, a panel of 250 firms was derived randomly from the entire population. It includes joint-stock and limited liability companies, all of which are subject to the corporate income tax. After some necessary corrections the sample was limited to 218 corporations (1.275 firm-year observations). The simulation covers a period of 5 years (2008-2012). However, also data from 2007 are used since it enables to calculate changes in some items of the balance sheets necessary in the investigation.

\section{Microsimulation results}

The analysis starts with the changes in the average tax due induced by the deductibility of provisions. Then it concentrates on the distributional aspects of the changes in the tax base.

Table 1 shows how, on average, the individual corporate income tax changes if provisions are deductible from taxable earnings. In other words, it displays the relative average change in the multi-period tax due in the group of the analysed firms.

9 The nominal tax rate represents the real corporate income tax rate in Poland which is set at the level of $19 \%$ for the entire period.

${ }^{10}$ Consistently with the taxes due, cash flows are calculated at future values for the last period analyzed. The overall long-term amount of the cash flows is decisive for assigning a firm to a group characterized by positive or rather negative cash flow.

11 The annual percentage rate is derived from Polish treasury bonds. 
European Financial and Accounting Journal, 2015, vol.10, no. 4, pp. 19-31.

Tab. 1: Average change in corporate income tax due (in \%)

\begin{tabular}{ll}
\hline Group of firms & Average change in tax due $^{\mathbf{a}}$ \\
\hline Firms with $\mathrm{CF}>0$ & $-5,6$ \\
Firms with $\mathrm{CF}<0$ & $-9,8$ \\
\hline
\end{tabular}

Source: Own calculation based on InfoCredit database.

Note: Future value of annual taxes due, calculated for the end of the analysed period.

For firms which have positive cash flow over the entire analysed period the tax due decreases by 5,6\%, on average. Within the group of firms with negative cash flows the tax advantage is higher and it amounts to 9,8\%. Generally, the letter firms report lower annual corporate tax burden. The greater relative reduction of the corporate income tax in the group of firms with negative cash flow can be judged positively. An earlier tax-effective deduction, which is made already when provisions are created and not when the actual payment is made, is positive in terms of the time value of money concept and it makes firms with difficult financial situation better off.

The results vary strongly across firms. It is evident that there are companies for which the tax advantage induced by the deductibility of provisions leads to a zero tax base. This applies either to entities with relatively high amount of provisions and/or to firms with a relatively small initial tax base. For this reason, an analysis of the distribution of the changes in the tax burden gives additional insight into the problem of the scale of the tax advantages. It enables to observe to what extent single entities are influenced by the deductibility of provisions. It also allows to identify how big the effects which prevail are. In other words, it is investigated how big changes in multi-period corporate taxes due are expected in case provisions for future obligations are deductible for tax purposes. Table 2 displays the results. It reveals that the change in corporate income tax is distributed in different ways across firms.

Tab. 2: Distribution of the changes in corporate income tax (in \%) ${ }^{\text {a }}$

\begin{tabular}{lllllllll}
\hline Percentile & $\mathbf{1}$ & $\mathbf{5}$ & $\mathbf{1 0}$ & $\mathbf{2 5}$ & $\mathbf{5 0}$ & $\mathbf{7 5}$ & $\mathbf{9 7}$ & $\mathbf{1 0 0}$ \\
\hline Change in & $-73,1$ & $-25,6$ & $-15,3$ & $-5,6$ & $-1,0$ & $-0,1$ & 0,0 & 139,8 \\
CIT & \multicolumn{7}{c}{ Firms } & Fith CF>0 \\
Change in & $-100,0$ & $-61,7$ & $-36,7$ & $-8,5$ & $-2,0$ & 0,0 & 1,5 & 71,2 \\
CIT & &
\end{tabular}

Source: Own calculation based on InfoCredit database.

Note: Percentage change in the future value of firm's corporate income tax for the analysed period.

The reduction in the multi-period tax due induced by the deductibility of provisions as proposed in the CCCTB concept ranges from $1 \%$ to $2 \%$ for median companies for alternative cross-sections of taxpayers. $10 \%$ of firms with sound 
Leszczyłowska, A.: Deductibility of Provisions under the CCCTB Proposal and Its Effects on Companies: The Case of Poland.

liquidity situation experience a cut of the tax due of $15,3 \%$ and more. In the corresponding group of corporations with negative cash flows the reduction in tax is stronger and it amounts at least to $36,7 \%$. A decrease in the tax due is faced by about $75 \%$ of companies with positive cash flow whereas the tax burden of the remaining $25 \%$ of corporations remains unaffected by the analysed reform, or it increases. For about $50 \%$ of the entities located between $25^{\text {th }}$ and $75^{\text {th }}$ percentile there is a slight decrease of the tax burden which rangers from $8,5 \%$ (firms with $\mathrm{CF}<0$ ) and 5,6\% (firms with $\mathrm{CF}>0$ ) to $0,1 \%$ (firms with $\mathrm{CF}>0$ ).

\section{Fig. 1: Distribution of the changes in corporate income tax (in \%)}
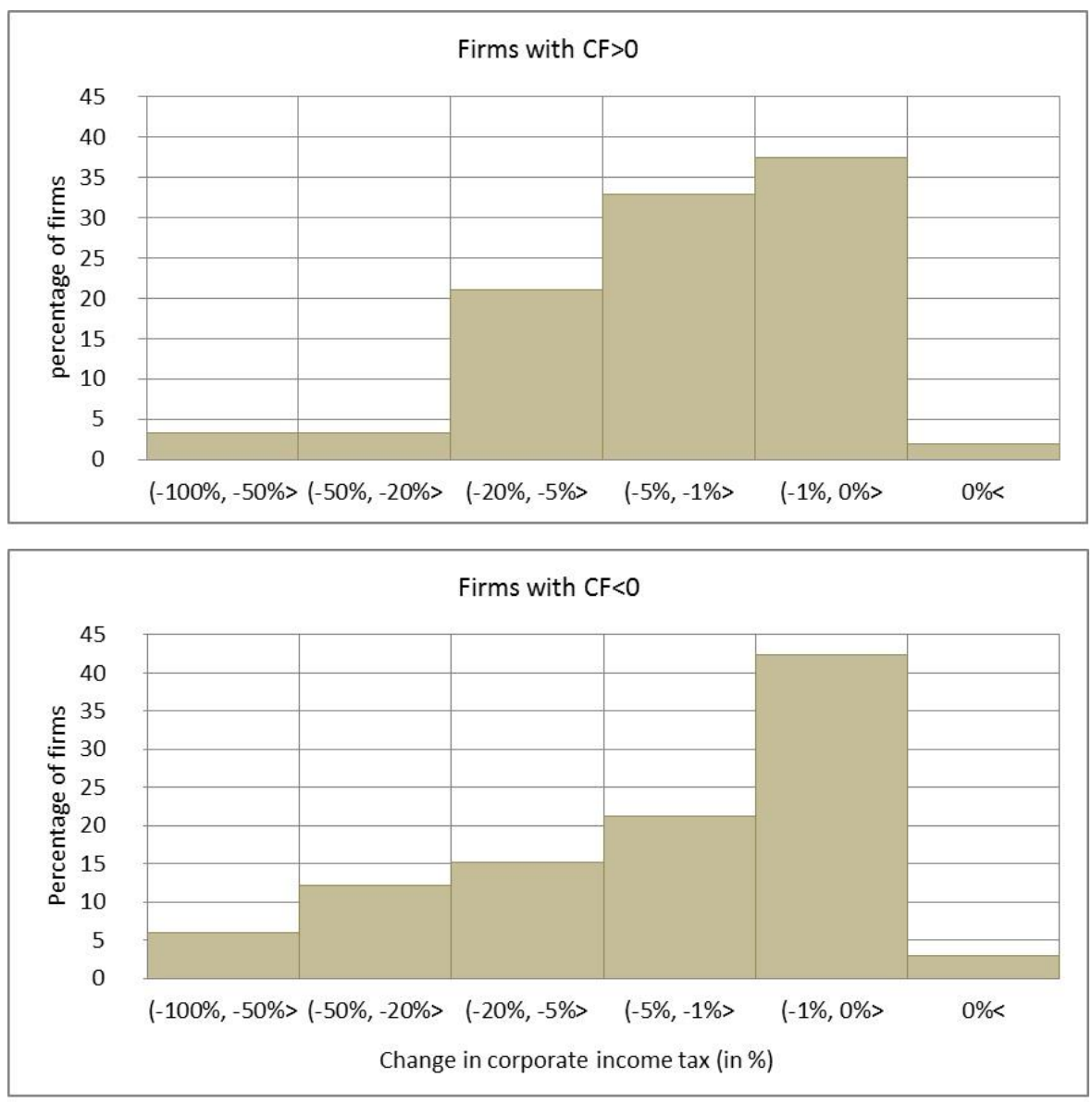

Source: Own calculation based on InfoCredit database.

As the results in this section are not corrected for outliers there can be observed single entities which face a remarkable increase in tax (over $2 \%$ of the sample). A 
reason for this is the current restricted rules on tax loss carry forward. In consequence it is thinkable that for certain combinations of taxable profits and losses over time some entities are unable to take advantage of the new, more generous tax rules on provisions. Although such companies constitute only a small fraction of the sample it is worth stressing that two types of effects can be identified for these firms. A primary effect consists in a reduction in the multiperiod tax burden due to the fact that the expenses for which provisions are reported are allowed to lower the taxable base in earlier periods. A secondary effect works in an opposite direction. Due to the limitation regarding the length of the period and the amount of tax loss carry forward the taxable profits of some entities are insufficient to take advantage of the deduction. As a consequence, the firms become worse-off as observed from a multi-period perspective.

The histograms presented in figure 1 confirm that the changes in the multi-period tax burden amount to at least several percent for the majority of companies. More significant decreases in tax duties are cumulated in the group of companies with negative cash flows over the entire analysed period. For instance, altogether $18 \%$ of all companies with lacking liquidity experience a reduction in tax of at least $20 \%$, whereas in the corresponding group of firms with positive cash flows such a strong reduction applies for merely $6 \%$ of the entire group. This should be positively evaluated taking the perspective of a taxpayer into account.

\section{Conclusion}

The case of Poland is interesting in the context of international comparisons of the effects which may emerge if the harmonized rules on the tax base are introduced in the EU. It was not the subject of the paper to investigate into what extent the investigated companies are representative for other European countries. However, the obtained results give a valuable insight into the potential consequences of the deductibility of provisions which can emerge in jurisdictions in which such a deductibility is currently not allowed or limited.

For the vast majority of enterprises, the deductibility of provisions leads to a tax advantage. It is, however, differently distributed among companies. Since for single entities the decrease in the income tax reaches $100 \%$, the vast majority of companies can expect a reduction of several percent. These differences depend e.g. on the role provisions play in firms' individual financial policy, their profitability and the scale of other items which lower the tax base.

The analysis conducted in the paper delivers directions for further extensions. Provisions are expected to be one of the major elements - but not the only one causing differences between the harmonization project and the national tax accounting practices across the EU. Provided the CCTB is introduced, it can be expected that besides the modified rules on provisions also depreciation and loss 
Leszczyłowska, A.: Deductibility of Provisions under the CCCTB Proposal and Its Effects on Companies: The Case of Poland.

carry forward will have great influence on company's taxation. Several simplifying assumptions connected with the structure and nature of provisions (e.g. whether they reflect deductible expenses) could be released or changed. Alternatively, a survey among a larger group of tax practitioners could be conducted in order to obtain more detailed information on the tendencies in the structure of provisions. Moreover, the number of winners and losers could be subject to analysis. The current Polish system of tax loss carry-forward can be replaced by the unrestricted inter-period loss offset as proposed by the directive. It can be expected that if the restrictions are abrogated there will be no increase in the tax burden among companies.

\section{References}

Cline, R., Neubig, T., Phillips, A., Sanger, C., Walsh, A., 2011. Study on the Economic and Budgetary Impact of the Introduction of a Common Consolidated Corporate Tax Base in the European Union. Ernst \& Young.

Devereux, M., Loretz, S., 2008. The Effects of EU Formula Apportionment on Corporate Tax Revenues. Fiscal Studies 29, 1-33.

Devereux, M., 2004. Debating Proposed Reform of the Taxation of Corporate Income in the European Union. International Tax and Public Finance 11, 71-89.

European Commission, 2011. Impact Assessment. Accompanying Document to the Proposal for a Council Directive on a Common Consolidated Corporate Tax Base (CCCTB). SEC(2011) 315, Brussels.

Finke, K., Heckemeyer, J., Reister, T., Spengel, C., 2013. Impact of Tax-Rate Cut cum Base-Broadering Reforms on Heterogeneous Firms: Learning from the German Tax Reform of 2008. FinanzArchiv 69, 72-114.

Fuest, C., Hemmelgarn, T., Ramb, F., 2007. How Would Formula Apportionment in the EU Affect the Distribution and the Size of the Corporate Tax Base? An Analysis Based on German Multinationals. International Tax and Public Finance 14, 605-626.

Leszczyłowska, A., 2013. Wspólna europejska podstawa opodatkowania a obciążenia podatkowe przedsiębiorstw w Polsce. Finanse 6, 147-169.

Leszczyłowska, A., 2014. The relationship between book profit and taxable income from a research perspective - evidence based on corporations in Poland. Journal of Economics and Management 18, 91-105.

McLure, C., Weiner, J. M., 2000. Deciding whether the European Union Should Adopt Formula Apportionment of Company Income. In S. Cnossen (Ed.), Taxing Capital Income in the European Union: Issues and Options for Reform. Oxford University Press, Oxford. 
Nerudová D., Solilová V., 2015. Kvantifikace dopadů zavedení společného konsolidovaného základu daně v Evropské Unii do celkového základu daně korporací vykazovaného v České Republice. Politicka ekonomie 4, 456-473.

Nerudová D., Solilová V., 2014. The Impacts of the CCCTB Introduction on the Distribution of the Group Tax Bases across the EU: The Study for the Czech Republic. In D. Stavarek, P. Vodova (Ed.), Proceedings of the 14th international conference on finance and banking, Ostrava, 308-319.

Oestreicher, A., Koch, R., 2008. Corporate average tax rates under the CCCTB and possible methods for international loss-offset. Working Paper No. 08-001, Georg-August Universität Göttingen.

Oestreicher, A., Koch, R., 2011. The Revenue Consequences of Using a Common Consolidated Corporate Tax Base to Determine Taxable Income in the EU Member States. FinanzArchiv 67, 64-102.

Oestreicher, A., Koch, R., Klett, M., 2008. Empirisch basierte Analyse von Auswirkungen der Unternehmensteuerreform 2008 mit Hilfe unternehmensbezogener Mikrodaten. Steuer und Wirtschaft 85, 15-26.

Oestreicher, A., Reister, T., Spengel, C., 2009. Common Corporate Tax Base (CCTB) and Effective Tax Burdens in the EU Member States. Discussion Paper No. 09-026, ZEW, Mannheim.

Oestreicher, A., Scheffler, W., Spengel, C., Finke, K., Heckemeyer, J., Kimpel, G., Köstler, M., Vorndamme, D., 2014. Gemeinsame KörperschaftsteuerBemessungsgrundlage (GKB) bzw. Gemeinsame UnternehmensteuerBemessungsgrundlage (GUB): Eine steuerliche Folgenabschätzung für Deutschland. Steuer und Wirtschaft 4, 326-343.

Reister, T., Spengel, C., Heckemeyer, J. H., Finke K., 2008. ZEW Corporate Taxation Microsimulation Model (ZEW TaxCoMM). Discussion Paper No. 08117, ZEW, Mannheim.

Reister, T., 2009. Steuerwirkungsanalysen unter Verwendung von unternehmensbezogenen Mikrosimulationsmodellen. Gabler, Wiesbaden.

Spengel, C., Zöllkau, Y. (Ed.), 2012. Common Corporate Tax Base (CC(C)TB) and Determination of Taxable Income. An International Comparison. Springer, Berlin, Heidelberg.

Spengel, C., Ortmann-Babel, M., Zinn, B., Matenaer, S., 2012. A Common Corporate Tax Base for Europe: An Impact Assessment of the Draft Council Directive on a CC(C)TB. Discussion Paper No. 12-039, ZEW, Mannheim.

Vašek L., Gluzová T., 2014. Can a New Concept of Control under IFRS Have an Impact on a CCCTB? European Financial and Accounting Journal 4, 110-127. 
